\title{
Keterwakilan Perempuan pada Pemilihan Anggota Dewan Perwakilan Rakyat Kabupaten Tulang Bawang Barat pada Pemilihan Umum (Pemilu) 2019
}

\author{
Ari Hervina ${ }^{1 *}$; Hertanto $^{2}$; Arizka Warganegara ${ }^{3}$ \\ Published online: 5 December 2021
}

\begin{abstract}
The breakthrough to achieve justice in the political field is the implementation of an affirmative action system, which is a system used globally to enable women to play their role, especially in the world of politics. The purpose of this research is to find out, analyze and explain what factors influence women's representation in the West Tulang Bawang Regency DPRD election results in 2019 and to find out, analyze and explain strategies for increasing women's representation in PDIP, Nasdem Party and Gerindra Party. As for those who became respondents in this study amounted to 7 people. The results of this research are 1) The factors that influence women's representation in the Legislative Election DPRD Tulang Bawang Barat Regency are 3 (three), namely political education, political communication and political culture and the most dominant factor influencing is "patriarchal culture" with the conclusion explanation as follows: The following: 1) Political education: political education efforts for legislative candidates, especially women, are not effectively implemented, this is due to time constraints and the reluctance of women legislative candidates to access and deepen knowledge about the world of politics, b) Political communication: political communication efforts the majority of legislative candidates only rely on the media mix and are less effective in direct political communication or interpersonal communication such as open campaigns or door to door. c) Political culture: patriarchal culture is still cultured, namely a culture that places women in a position that is always under men, is considered to have duties and responsibilities in domestic management of the household, namely kitchens, wells and mattresses. And 2) The strategy to increase women's representation in PDIP, Nasdem Party and Gerindra Party is carried out in 3 (three) ways, namely a) Increasing political education, b) Increasing political marketing and c) Increasing women's political participation.
\end{abstract}

Keywords: Election, Legislative and Women

\section{PENDAHULUAN}

Pemilihan umum legislatif di Indonesia baik tingkat daerah maupun pusat yang diselenggarakan setiap lima tahun sudah dilaksanakan secara langsung. Melalui pemilihan umum ini ada asa dan harapan untuk perbaikan bangsa ke depan, terlebih memperbaiki kualitas demokrasi dan melanjutkan proses pembangunan dalam rangka meningkatkan kesejahteraan rakyat. Permasalahannya sekarang adalah partisipasi politik perempuan di Indonesia di nilai masih rendah, hal tersebut dibuktikan dengan

\footnotetext{
$\overline{1,2}$ Magister Ilmu Pemerintahan FISIP Universitas Lampung

*) corresponding author

Ari Hervina

Mahasiswa Magister Ilmu Pemerintahan FISIP

Universitas Lampung

Jalan Prof. Dr. Soemantri Brojonegoro No. 01 Bandar Lampung

Email: arihervina2000@gmail.com
}

masih sedikitnya kaum perempuan yang mau terjun kedunia politik, dan kalau pun ada itu hanya sebatas formalitas saja untuk memenuhi kuota atau memenuhi persyaratan sebagaimana yang telah dijelaskan dalam Jurnal Etika dan Pemilu yang diterbitkan oleh DKPP RI pada Undang-Undang Republik Indonesia Nomor 7 Tahun 2017 Tentang Pemilihan Umum Pasal 245 yang menyebutkan daftar bakal calon sebagaimana dimaksud dalam Pasal 243 (daftar bakal calon anggota DPR tingkat pusat, provinsi dan DPRD kabupaten/kota) harus memuat keterwakilan perempuan paling sedikit 30\% (tiga puluh persen).

Lebih lanjut jurnal hasil penelitian Listyaningsih (2014) menyebutkan partisipasi perempuan dalam politik masih dipersepsikan pada representasi dalam struktur politik di tingkat nasional maupun daerah, yang dirasakan belum memadai, realitas partisipasi politik kaum perempuan di lembaga legislatif sejak tahun 1999 hingga 2014 baru berkisar pada angka 8,8\% di tingkat pusat, 6,6\% di tingkat Provinsi, dan $2 \%$ di tingkat Kabupaten/kota, hal ini merupakan gambaran nyata partisipasi perempuan dalam 
lembaga-lembaga politik formal yang sering digunakan sebagai dasar argumentasi pentingnya penguatan peran melalui kebijakan-kebijakan yang besifat affirmatif terhadap potensi yang dimiliki kaum perempuan belum sepenuhnya terwakili. Data yang penulis peroleh di tingkat Provinsi Lampung juga menunjukkan gejala yang sama yaitu keterwakilan perempuan sejak pemilihan umum periode 1999 sampai dengan periode 2019 pada tingkat provinsi atau DPRD provinsi tidak pernah mencapai target kuota 30\% dimana pada periode tahun 1999-2004 hanya mencapai $15 \%$, periode tahun 2004-2009 sebesar $12 \%$, periode tahun $2009-2014$ sebesar $20 \%$ dan periode tahun 2014-2019 sebesar $13 \%$.

Kabupaten Tulang Bawang Barat merupakan salah satu kabupaten yang pada tanggal 17 April 2019 telah ikut melangsungkan pemilihan umum melalui pemilihan calon legislatif tingkat daerah. Keputusan Komisi Pemilihan Umum RI Nomor 271/PL.01.3-Kpt/06/KPU/IV/2018 tentang penetapan dan alokasi kursi DPRD provinsi/kabupaten/kota maka Daerah Pemilihan (Dapil) di Kabupaten Tulang Bawang Barat terbagi ke dalam 4 (empat) Daerah Pemilihan (Dapil) yakni Dapil I meliputi Kecamatan Tulang Bawang Tengah (9 kursi), Dapil II meliputi Kecamatan Pagar Dewa, Kecamatan Lambu Kibang, Kecamatan Gunung Terang dan Kecamatan Batu Putih), (7 kursi), Dapil III meliputi Kecamatan Gunung Agung dan Kecamatan Way Kenanga (6 kursi), Dapil IV meliputi Kecamatan Tumijajar dan Kecamatan Tulang Bawang Udik (8 kursi), sehingga jumlah kursi yang diperebutkan pada pemilihan legislatif tahun 2019 adalah sebanyak 30 kursi parlemen

Sejak pemilu legislatif Kabupaten Tulang Bawang Barat juga tidak pernah mencapai kuota $30 \%$, hal tersebut terlihat pada pemilu legislatif periode 2014-2019, dari 30 anggota DPRD Kabupaten Tulang keterwakilan perempuan hanya 2 orang $(6,7 \%)$ yaitu dari partai Hanura dan PAN, demikian halnya pada pemilu legislatif periode 2019-2024 hanya ada 1 (satu) perempuan atau (3,3\%) yang terpilih dalam kontestan pemilihan legislatif, yaitu dari partai Demokrat, lagi-lagi ini menunjukkan bahwa kuota perwakilan perempuan yang duduk di parlemen tidak memenuhi target. Kurang tercapainya keterwakilan perempuan pada pemilihan umum legislatif di Kabupaten Tulang Bawang Barat sejalan dengan hasil penelitian yang dilakukan oleh beberapa peneliti terdahulu diantaranya hasil penelitian terdahulu yang dilakukan oleh Novi Yanthy Adelina (2014), dalam Jurnal Fakultas Hukum Universitas Andalas dengan judul Keterwakilan Perempuan di Dewan Perwakilan Rakyat Daerah Provinsi Sumatera Utara Periode 20092014, di dapat hasil bahwa Keterwakilan perempuan DPRD Provinsi Sumatera Utara periode 2009-2014, dari 100 orang anggota legislatif, hanya ada 16 orang saja perwakilan wanitanya artinya hanya $16 \%$ saja keterwakilan perempuan. Selanjutnya hasil penelitian terdahulu yang dilakukan oleh Ukhti Raqim (2016) dalam Jurnal Fisipol, Universitas Negeri Semarang dengan judul Implementasi ketentuan kuota 30\% keterwakilan perempuan di DPRD Kota Salatiga di dapat hasil bahwa implementasi ketentuan kuota 30\% keterwakilan perempuan di DPRD Kota Salatiga sudah terimplementasi, akan tetapi dalam pelaksanaan pemenuhannya belum terpenuhi hingga angka $30 \%$. Demikian halnya dengan hasil penelitian terdahulu yang dilakukan oleh Feybe M.P Wuisan (2016) dalam Jurnal Fisipol, Universitas Prof. Dr. Moestopo (Beragama) Jakarta dengan judul Keterwakilan perempuan dalam politik di lembaga legislatif (suatu kajian pada DPRD kota Tomohon periode 2009-2014) di dapat hasil bahwa partisipasi kaum perempuan menjadi anggota legislatif dipengaruhi oleh rendahnya wawasan dan pengetahuan dalam bidang politik, selain itu dipengaruhi oleh masih kuatnya budaya patriarkhi yang telah melekat bagi setiap anggota DPRD laki-laki sehingga seringkali dalam proses persaingan untuk memperoleh/meraih jabatan strategis dalam bidang politik kaum wanita jauh tertinggal.

Hasil penelitian terdahulu lain yang dilakukan oleh Nofi Sri Utami (2016) dalam Jurnal Fakultas Hukum, Universitas Negeri Semarangdengan judul Politik Hukum Keterwakilan Perempuan di Lembaga Legislatif Era Reformasi di dapat hasil bahwa banyaknya partai politik yang menganggap bahwa kuota $30 \%$ keterwakilan perempuan hanya sekedar prasyarat untuk lolos dalam pemilu, tetapi di sisi lain partai politik tidak melihat kwalitas perempuan yang dicalonkan sebagai calon legislatif. Sama hal nya dengan hasil penelitian terdahulu yang dilakukan oleh Sri Zul Chairiyah (2019) dalam Jurnal Fisipol Universitas Andalas, Sumatera Baratdengan judul Perkembangan Keterwakilan Politik Perempuan di DPRD Provinsi Sumatera Barat (Studi Komparatif Kebijakan Affirmative Action Periode Pemilu Legislatif 2004-2014) di dapat hasil bahwa perkembangan keterwakilan politik perempuan di DPRD Provinsi Sumatera Barat belum menunjukkan hal yang positif. Perempuan terpilih di lembaga legislatif belum mampu mencapai angka minimal 30\% Senada dengan hasil penelitian terdahulu yang dilakukan oleh Totok Inwantoro (2019) dalam Jurnal Fakultas Ilmu Sosial dan Ilmu Politik Universitas Diponegoro dengan judul Faktor-Faktor Yang Memengaruhi Redahnya Tingkat Partisipasi Politik Perempuan Pada Pemilu Legislatif DPRD Kabupaten Mojokerto 2014 di dapat hasil bahwa rendahnya tingkat partisipasi politik perempuan di Kabupaten Mojokerto secara garis besar dikarenakan oleh beberapa faktor. yang pertama ialah budaya patriarki. Faktor kedua ialah masih rendahnya kualitas perempuan baik itu di bidang politik maupun bidang sosial, seperti dalam bidang ekonomi.

Kemudian hasil penelitian terdahulu yang dilakukan oleh Mursal Maherul (2019) dalam Jurnal FISIP Universitas Indonesia dengan judul Analisis Penyebab Rendahnya Tingkat Keterpilihan Perempuan dalam Upaya Representasi Politik Perempuan pada Pemilu Tahun 2014 di dapat hasil bahwa rendahnya tingkat keterpilihan perempuan disebabkan oleh berbagai hambatan; yaitu; pertama, jumlah voters turnout yang rendah; kedua, masalah keanggotaan di partai politik yang berbasis kekerabatan; ketiga; masalah kaderisasi dan pendidikan politik yang rendah; keempat, masih menguatnya budaya patriarki dalam tatanan masyarakat, dan kelima, calon legislatif perempuan cenderung ditempatkan pada nomor urut. dan inilah alasan yang membuat peneliti tertarik untuk meneliti lebih mendalam di Kabupaten Tulang Bawang Barat Berdasarkan latar belakang di atas maka judul penelitian tesis ini adalah "Keterwakilan Perempuan pada DPRD Kabupaten Tulang Bawang Barat Hasil Pemilu Tahun 2019"

Penelitian ini mempunyai tujuan untuk mengetahui, menganalisis dan menjelaskan faktor-faktor apa saja yang mempengaruhi keterwakilan perempuan pada DPRD Kabupaten Tulang Bawang Barat hasil pemilu tahun 2019 serta untuk mengetahui, menganalisis dan menjelaskan strategi peningkatan keterwakilan perempuan pada PDIP, Partai Nasdem dan Partai Gerindra.

\section{METODE PENELITIAN}

Jenis penelitian yang digunakan dalam penelitian ini adalah penelitian kualitatif. Alasan peneliti hanya menggunakan jenis penelitian kualitatif adalah 
dikarenakan dalam menganalisa hasil penelitian hanya bersifat mendiskripsikan atau menggambar kan suatu fenomena dengan alat ukur wawancara, yaitu untuk mengetahui, faktor-faktor apa saja yang mempengaruhi keterwakilan perempuan pada DPRD Kabupaten Tulang Bawang Barat hasil pemilu tahun 2019 serta untuk mengetahui, menganalisis dan menjelaskan strategi peningkatan keterwakilan perempuan pada PDIP, Partai Nasdem dan Partai Gerindra.

Adapun yang menjadi sumber informasi Sumber informan pada penelitian ini dipilih secara non random atau tidak secara acak dengan menggunakan teknik purposive yaitu menentukan narasumber yang diwawancarai pada objek penelitian yang berkaitan dengan permasalahan atau fokus penelitian Alasan peneliti menggunakan purposive bertujuan untuk mengambil informan secara objektif, dengan angapan bahwa informan yang diambil itu merupakan keterwakilan (refresentatif) bagi peneliti, sehingga pengumpulan data yang langsung pada sumber datanya dapat dilakukan secara proporsional demi keakuratan penelitian. Selain itu data yang digunakan dalam penelitian ini merupakan data homogen yang artinya bahwa data yang dipakai dalam penelitian ini adalah sama sehingga informan yang diwawancarai cukup sebagian. Teknik pengumpulan data adalah dengan 1) Wawancara Mendalam (Indepth-Interview), 2) Observasi, dan 3) Dokumentasi. Teknik analisa data yaitu 1) Reduksi data, 2) Penyajian data, 3) Triangulasi data dan 4) Menarik kesimpulan.

\section{HASIL PENELITIAN}

Pendapat Soetjipto (2015:89), yang menyatakan pengertian gender adalah seks (jenis kelamin) merupakan dua hal yang berbeda, tetapi pengertiannya sering dicampur adukkan. Gender secara umum digunakan untuk mengidentifikasi perbedaan laki-laki dan perempuan dari segi sosial budaya. Sementara itu, seks secara umum digunakan untuk mengidentifikasi perbedaan laki-laki dan perempuan dari segi anatomi biologis. Berkaitan dengan keterwakilan perempuan, Soetjipto (2015:40) menjelaskan bahwa affirmative action keterwakilan perempuan dalam daftar bakal calon dilakukan tidak hanya untuk DPR, tetapi berlaku pula untuk DPRD Provinsi maupun DPRD Kabupaten/Kota. Kuota diperlukan agar terjadi keseimbangan dan untuk mencapai critical mass (angka strategis). Representasi yang dianggap signifikan adalah bila partisipasi perempuan mencapai angka presentase 30\%. Pendapat lain dikemukan Ihromi (2015:499) yang menyatakan keterwakilan politik perempuan adalah kegiatan sebagai warga maupun sebagai anggota organisasi partai politik (orang seorang atau kelompok-kelompok), yang memiliki peran secara sadar memberikan pemikiranpemikiran, pengaturan, mulai dari penentuan tujuan sampai dengan penyelenggaraannya, sehingga tercapai tujuan.

Pentingnya keterwakilan politik perempuan adalah kegiatan politik yang dilakukan oleh perempuan, dalam upaya penyesuain gender, persamaan hak dengan laki-laki untuk memperjuangkan aspirasinya dalam pengambilan keputusan di parlemen. Kehadiran perempuan dalam lembaga pembuat keputusan seperti lembaga legislatif dengan kuota keterwakilan mencapai 30\%, dipandang sebagai keharusan untuk memperjuangkan hak perempuan yang diharapkan dapat mematahkan pelabelan yang diberikan kepada perempuan bahwa perempuan adalah makhluk lemah yang tidak layak berjuang dalam pengambilan kebijakanKehadiran perempuan ini juga di harapkan dapat membawa gaya pendekatan politik yang lebih ramah dan sejuk serta mampu mengimbangi ketamakan anggota legislatif laki-laki karena perempuan mengelola lebih pada hati. Pernyataan di atas sesuai dengan argumen pentingnya kehadiran perempuan dalam politik yang disampaikan oleh para pakar pilitik yaitu pertama, argumen keadilan yang berarti sangatlah tidak adil jika kaum laki-laki memonopoli perwakilan, kedua argumen pragmatis di mana melalui partisipasi perempuan, politik akan lebih konstruktif dan ramah. Perempuan dan politik adalah wacana yang menarik untuk diperbincangkan dan menjadi suatu hal yang politis untuk diperdebatkan. Peranan perempuan dalam menjalankan fungsinya di badan legislatif belum mendapatkan tempat yang strategis, kedudukan laki-laki yang lebih mendominasi dan dalam menentukan kebijakan publik, biasanya perempuan hanya menjadi peserta dan penikmat kebijakan saja.

Teori yang di pakai berkaitan dengan faktor-faktor yang dapat mempengaruhi keterwakilan politik perempuan pada pemilu legislatif, mengutip pendapat Anugrah (2016:177) diantaranya adalah pendidikan politik, komunikasi politik, dan budaya politik. Alasan peneliti menggunakan teori yang dikutip oleh Anugrah (2016:177) adalah dikarenakan faktor yang paling dominan mempengaruhi keterwakilan politik perempuan pada pemilu legislatif yaitu disebabkan karena kurangnya pendidikan politik yang diberikan oleh partai politik terhadap calon legislatif, sehingga berdampak kurangnya pengetahuan calon legislatif perempuan tentang dunia politik, selain itu rendahnya komunikasi politik yang dilakukan oleh calon legislatif perempuan terhadap pemilih (masyarakat) sehingga pemilih kurang mengenal calon serta membudayanya budaya politik patriaki, dimana budaya ini masih melekat kental dikehidupan masyarakat, sehingga membatasi ruang gerak calon legislatif perempuan dalam usaha mencari dukungan, karena budaya ini menggangap bahwa perempuan tidak layak untuk terjun ke dunia politik, karena sudah kodratnya perempuan bekerja pada pekerjaan domestik (kasur, sumur dan dapur), oleh karena itu pada penelitian ini peneliti ingin mengetahui apakah ke 3 (tiga) faktor tersebut dapat mempengaruhi keterwakilan perempuan dalam pemilu legislatif DPRD Kabupaten Tulang Bawang Barat.

\section{Faktor-Faktor yang Mempengaruhi Keterwakilan Perempuan pada DPRD Kabupaten Tulang Bawang Barat hasil pemilu tahun 2019}

Keterwakilan perempuan dalam lembaga-lembaga strategis pembuat keputusan dalam hal ini lembaga legislatif sangatlah rendah. Demikian halnya keterwakilan perempuan pada DPRD Kabupaten Tulang Bawang Barat hasil pemilu tahun 2019. Mengutip pendapat Anugrah (2009:177) ada 3 (tiga) faktor yang mempengaruhi keterwakilan perempuan yaitu a) Pendidikan politik b) Komunikasi politik dan c) Budaya politik. Berikut dijelaskan secara rinci berdasarkan hasil wawancara dengan sejumlah narasumber, berkaitan dengan faktorfaktor yang mempengaruhi keterwakilan perempuan menjadi legislator Kabupaten Tulang Bawang Barat pada pemilu legislatif periode 2019-2024:

\section{a) Pendidikan Politik}

Hasil penelitian dapat ditarik suatu kesimpulan bahwa upaya pendidikan politik yang dilakukan oleh partai politik 
terhadap calon legislatif khusunya pada kaum perempuan kurang efektif dilaksanakan, hal tersebut disebabkan karena keterbatasan waktu dan enggan nya calon legislatif perempuan untuk mengakses dan memperdalam pengetahuan tentang dunia perpolitikan, yang pada akhirnya berdampak pada kurang tertariknya masyarakat untuk memilihnya menjadi wakil di parleman sehingga hasil akhir yang didapat kuota 30\% yang diamanatkan oleh Undang-Undang tidak terpenuhi.

Mewujudkan tujuan partai politik tersebut tentu tidak lepas dari peran calon legislatif yang berkualitas, calon legislatif yang mampu menjabarkan visi-misi partai yang mengusung nya. Salah satu upaya untuk mendapatkan calon legislatif yang berkualitas sehingga pemilih tertarik untuk menjadikan nya sebagai wakil di parlemen untuk membawa aspirasi pemilih, dibutuhkan suatu upaya partai politik untuk memberikan pendidikan politik kepada calon legislatif.

Hal tersebut sejalan dengan pendapat Azis (2012:116) yang menyatakan bahwa pendidikan politik bertujuan agar terbentuknya watak atau keperibadian bangsa Indonesia yang terbentuk atas dasar kesepahaman bersama terhadap nilai-nilai kebangsaan yang lahir dan tumbuh dalam kehidupan bangsa. Oleh karena itu, pendidikan politik dan perkaderan partai menjadi langkah peningkatan kualitas kehidupan berbangsa warga negara.

Senada dengan pendapat Naning (2012:67) berkaitan dengan pendidikan politik menyatakan bahwa pendidikan politik dapat dilakukan dengan proses dialog, kurus, seminar, dan sebagainya, dengan satu tujuan yaitu untuk mentransformasikan nilai, ideologi dan norma politik ke calon legislatif. Melalui pendidikan politik diharapkan dapat mewujudkan kesadaran dan partisipasi berdemokrasi dalam meningkatkan pengetahuan politik bagi masyarakat khusunya kaum perempuan untuk mendorong peningkatan partisipasi secara maksimal dalam sistem politik.

\section{b) Komunikasi Politik}

Hasil penelitian dapat ditarik suatu kesimpulan bahwa upaya komunikasi politik yang dilakukan oleh calon legislatif khusunya pada kaum perempuan kurang efektif dilaksanakan, hal tersebut terlihat para calon legislatif perempuan mayoritas hanya mengandalkan atau menggunakan bauran media untuk mengangkat popularitas, komunikasi politik lebih banyak menggunakan alat peraga kampanye seperti baleho, spanduk atau melalui media sosial seperti facebook, instagram, serta kurang efektif melakukan komunikasi politik secara langsung atau komunikasi interpersonal seperti kampanye terbuka atau door to door. Selain minimnya komunikasi interpersonal, para calon legislatif perempuan juga biasanya hanya berpangku tangan mengandalkan dukungan dari pihak keluarga maupun teman, kurang berkoneksi memanfaatkan tokoh masyarakat, tokoh agama tim sukses sebagai komunikator dalam menggalang suara. Minimnya komunikasi politik yang dilakukan calon legislatif perempuan disebabkan terbatasnya anggaran disebabkan karena mahalnya "mahar politik" serta, keterbatasan waktu untuk melakukan komunikasi politik.

Dalam suatu pertarungan atau kontestasi diperlukan suatu strategi untuk mencapai kemenangan dan menghindari kekalahan, strategi merupakan penentu utama dari keberhasilan suatu kegiatan. Sejak memasuki era kemajuan demokrasi di Indonesia 1998, berdampak kepada Pemilihan Umum (Pemilu) yang sistemnya semakin mengalami kemajuan, salah satunya dengan adanya pemilihan calon legislatif secara langsung. Undang-
Undang Nomor 8 Tahun 2012 tentang Pemilu pasal 215 dinyatakan bahwa penetapan calon legislatif ditentukan dengan sistem suara terbanyak bukan berdasarkan nomor urut. Hal ini menyebabkan para calon legislatif menjadi lebih aktif dan melakukan strategi untuk memenangkan pemilu salah satunya melalui komunikasi politik. Sesuai dengan pendapat Nihiyah (2013:97) yang menyatakan bahwa komunikasi politik merupakan proses penyampaian pesan yang bertujuan untuk mengubah sikap, pendapat dan tingkah laku pemilih. Perubahan ini ingin dicapai melalui himbauan, ajakan, dan janji sehingga membuat warga atau kelompok masyarakat tertarik dan simpati untuk menjatuhkan pilihan politiknya pada partai atau kandidat tertentu. Sejalan dengan pendapat Rogers dan Storey (2008:192) pengertian komunikasi politik adalah suatu proses yang dirancang secara sadar, bertahap dan berkelanjutan yang dilaksanakan pada rentang waktu dengan tujuan mempengaruhi khalayak sasaran yang telah ditetapkan).

\section{c) Budaya Politik}

Hasil wawancara di atas dapat ditarik suatu kesimpulan bahwa budaya patriarki masih membudaya di Indonesia khususnya di Provinsi Lampung. Budaya Patriarki adalah budaya yang menempatkan laki-laki sebagai sosok otoritas utama yang sentral dan memiliki posisi kekuasaan politik tertinggi serta menempatkan perempuan pada posisi yang selalu berada di bawah laki-laki. Budaya ini juga menganggap laki-laki lebih tepat untuk terjun ke kancah perpolitikan karena sudah menjadi tugas laki-laki untuk bekerja mencari nafkah, sedangkan perempuan dianggap memiliki tugas dan tanggung jawab dalam domestik pengurusan rumah tangga yaitu dapur, sumur dan kasur.

Hasil penelitian di atas dapat ditarik suatu kesimpulan bahwa adanya budaya politik dalam hal ini budaya patriarki merupakan salah satu faktor yang mempengaruhi keterwakilan perempuan dalam pemilu legislatif khususnya pada pada DPRD Kabupaten Tulang Bawang Barat hasil pemilu tahun 2019. Dalam budaya patriarki yang lebih mengutamakan laki-laki atau menganggap bahwa laki-laki paling utama dari perempuan dalam bidang politik, sehingga perempuan kurang diperhatikan di bidang politik. Mengutip pendapat Rohyati (2009:90) berkaitan dengan budaya patriaki yang menyatakan bahwa salah satu faktor yang membuat perempuan kurang percaya diri untuk maju ke arena politik adalah adanya budaya patriarki. Perempuan ingin melangkah ke arena politik tetapi masaih kurang percaya diri, budaya patriarki masih melekat dalam kehidupan masyarakat, dalam budaya patriarki, posisi kaum laki-laki paling utama daripada perempuan dan menganggap bahwa perempuan lebih identik dalam mengurus rumah tangga dan keluarga.

Sejalan dengan pendapat Lovenduski (2017:187) yang juga mengatakan bahwa salah satu kendala minimnya keterpilihan caleg perempuan adalah faktor sosial yang terdiri dari sumber daya perempuan, pemahaman bahwa perempuan memiliki tanggung jawab dalam keluaga yang tidak dapat ditinggalkan serta pemahaman bahwa politik adalah pekerjaan laki-laki. Setiap perempuan disubordinasi sebagai makhluk yang emosional sehingga lebih cocok bekerja di sektor domestik (dapur, rumah tangga/keluarga). Caleg perempuan juga dilabelkan sebagai ibu rumah tangga yang tidak dapat bekerja di luar keluarganya atau di wilayah laki-laki, termasuk lembaga legislatif. Inilah kenyataan yang terungkap dalam penelitian bahwa para pemilih meragukan kemampuan caleg perempuan karena faktor kultural yang masih melekat dalam proses pemilihan 


\section{d) Faktor Lain yang Mempengaruhi}

Hasil penelitian dapat diketahui juga bahwa terdapat beberapa faktor lain yang yang mempengaruhi keterwakilan perempuan dalam pemilu legislatif diantaranya adalah 1) Bagron, latar belakang, rekam jejak, integritas serta kualitas dari calon itu sendiri, 2) Ketersedian, kecukupan dana (modal) sebagai ongkos politik dan menyokong calon legislatif untuk melakukan mobilitas politik, 3) Money politic untuk memuluskan langkah menjadi legislator agar pemilih mau memilihnya pada saat pemilihan berlangsung, 4) Adanya dukungan yang mengalir baik dari dukungan partai politik maupun dukungan segenap elemen. Hasil wawancara dapat ditarik asumsi bahwa "budaya patriaki" merupakan faktor yang paling dominan dalam mempengaruhi keterwakilan perempuan dalam kontes pesta demokrasi yaitu pemilihan legislatif.

Katerwakilan perempuan dalam dalam pemilu legislatif ditunjang oleh beberapa faktor, mengutip pendapat Rusli (2016:152) yang menyatakan bahwa sudah menjadi rahasia umum bahwa peserta pemilu harus menyiapkan dana tidak sedikit untuk maju menjadi kepala daerah, anggota legislatif, ataupun presiden, artinya ketersedian dana merupakan salah satu faktor yang mendukung calon untuk dapat maju memenangkan pesta demokrasi. Kemudian yang tidak kalah pentingnya adalah vigur atau kualitas sosok calon tersebut, jika pemilih memiliki persepsi yang baik tentang latar belakang calon tersebut maka suatu keniscahyaan pemilih tidak memilihnya pada saat pesta demokrasi berlangsung.

Menurut Soetjipto (2015:178) ada 6 (enam) faktor yang mempengaruhi keterwakilan perempuan dalam pemilihan legislatif yaitu: (1) Dominasi model politik maskulin; (2) Rendahnya dukungan partai politik; (3) Kurangnya sumber daya keuangan perempuan; (4) Peran ganda perempuan antara di ruang domestik dan profesional; (5) Masih kentalnya ideologi dan tradisi patriarki; dan (6) Rendahnya persepsi diri mengenai partisipasi perempuan dalam politik.

\section{Strategi Peningkatan Keterwakilan Perempuan pada PDIP, Partai Nasdem dan Partai Gerindra}

Hasil wawancara di atas diketahui bahwa ada 3 (tiga) strategi yang dilakukan oleh PDIP, Partai Nasdem dan Partai Gerindra dalam upaya meningkatkan keterwakilan perempuan pada pemilihan umum legislatif di Kabupaten Tulang Bawang Barat, diantaranya adalah 1) Meningkatkan pendidikan politik, meningkatkan pengetahuan, pemahaman pola fikir, wawasan khususnya yang berkaitan dengan politik hal ini penting sebagai amunisi caleg perempuan untuk menyuarakan kepentingan dan tujuan parpol, 2) Meningkatkan marketing politic yaitu dengan cara mendampingi, mengawasi caleg terutama perempuan untuk bergerak aktif melakukan sosialisasi, komunikasi kedaerah dapilnya masing-masing, sebagai ajang untuk mempromosikan visi-misi partai dan mempromosikan kandidat caleg terutama perempuan agar lebih dikenal oleh masyarakat selaku pemilih sehingga masyarakat selaku pemilih tertarik, simpati untuk memilih caleg tersebut pada saat pemilihan legislatif berlangsung, dan 3) Meningkatkan partisipasi politik perempuan, merekrut kader-kader sebanyak mungkin sehingga caleg DPRD perempuan yang di usung partai lebih mendominasi dibandingkan laki-laki atau setidaknya memenuhi kuota 6 laki dan 6 perempuan, hakl tersebut berkaca pada pemilu 2019 yang lalu, hampir disemua dapil 1-IV caleg dari semua partai didominasi oleh caleg laki-laki, artinya partisipasi perempuan untuk mengikuti ajang pemilu masih sangat rendah

Hasil wawancara di atas diketahui bahwa ada 3 (tiga) strategi yang dilakukan oleh PDIP, Partai Nasdem dan Partai Gerindra dalam upaya meningkatkan keterwakilan perempuan pada pemilihan umum legislatif di Kabupaten Tulang Bawang Barat, diantaranya adalah:

a) Meningkatkan pendidikan politik: Mengutip pendapat Kantaprawira (2014:189) pendidikan politik merupakan sutu proses dialogis antara pemberi dan penerima pesan, melalui proses ini para anggota partai politik mengenal dan mempelajari nilai-nilai, normanorma, dan symbol partai politik nya. Kemudian pendapat lain seperti yang di ungkapkan Kartini (2011:171) bahwa pendidikan politik adalah suatu bentuk pendidikan yang dijalankan secara sengaja, terencana baik dalam bentuk formal ataupun informal yang mengajarkan setiap individu yng berkiprah di dunia politik agar sikap dan perbuatannya sesuai dengan aturan-aturan yang berlaku, dan mampu memahami maksud, tujuan, visi, misi partai politik yang diikutinya.

b) Meningkatkan marketing politic yaitu dengan cara mendampingi, mengawasi caleg terutama perempuan untuk bergerak aktif melakukan sosialisasi, komunikasi kedaerah dapilnya masing-masing, sebagai ajang untuk mempromosikan visi-misi partai dan mempromosikan kandidat caleg terutama perempuan agar lebih dikenal oleh masyarakat selaku pemilih sehingga masyarakat selaku pemilih tertarik, simpati untuk memilih caleg tersebut pada saat pemilihan legislatif berlangsung. Menurut Haroen (2014:116), pemasaran politik adalah penerapan konsep dan metode marketing ke dalam dunia politik. Marketing diperlukan untuk menghadapi persaingan dalam memperebutkan pasar (market), yang dalam hal ini adalah para pemilih

c) Meningkatkan partisipasi politik perempuan, merekrut kader-kader sebanyak mungkin sehingga caleg DPRD perempuan yang di usung partai lebih mendominasi dibandingkan laki-laki atau setidaknya memenuhi kuota 6 laki dan 6 perempuan, Berdasarkan Sensus Penduduk 2019, jumlah perempuan potensial di Kabupaten Tulang Bawang Barat adalah 123.000 jiwa, namun partisipasi perempuan yang mengikuti persaingan menuju kursi legislatif pada pemilu 2019 yang lalu hanya berjumlah 133 orang, hampir disemua dapil 1-IV caleg dari semua partai didominasi oleh caleg laki-laki, artinya partisipasi perempuan untuk mengikuti ajang pemilu masih sangat rendah. Partisipasi politik menurut Hutington dan Nelson yang dikutip oleh Cholisin (2017: 151) adalah kegiatan warga Negara yang bertindak sebagai pribadi-pribadi yang dimaksud untuk mempengaruhi pembuatan keputusan oleh pemerintah. Selanjutnya Ramlan Surbakti sebagaimana yang dikutip oleh Cholisin (2007:150) memberikan definisi singkat mengenai partisipasi politik sebagai bentuk keikutsertaan warga negara biasa dalam menentukan segala keputusan yang menyangkut atau mempengaruhi hidupnya

\section{KESIMPULAN}

Kesimpulan penelitian merujuk kepada tujuan penelitian, yaitu ada 2 (dua):

1. Faktor-faktor yang mempengaruhi keterwakilan perempuan dalam Pemilu Legislatif DPRD Kabupaten 
Tulang Bawang Barat ada 3 (tiga) yaitu: a) Pendidikan politik: upaya pendidikan politik yang dilakukan oleh partai politik terhadap calon legislatif khusunya pada kaum perempuan kurang efektif dilaksanakan, hal tersebut disebabkan karena keterbatasan waktu dan calon legislatif perempuan kurang mengakses dan memperdalam pengetahuan tentang dunia perpolitikan, b) Komunikasi politik: upaya komunikasi politik yang dilakukan oleh calon legislatif kaum perempuan kurang efektif dilaksanakan, komunikasi politik lebih banyak menggunakan alat peraga kampanye seperti baleho, spanduk atau melalui media sosial serta kurang efektif melakukan komunikasi politik secara langsung kampanye terbuka atau door to door; c) Budaya politik: budaya patriarki masih membudaya yaitu budaya yang menempatkan perempuan pada posisi yang selalu berada di bawah laki-laki, dianggap memiliki tugas dan tanggung jawab dalam domestik pengurusan rumah tangga yaitu dapur, sumur dan kasur.

2. Strategi peningkatan keterwakilan perempuan pada PDIP, Partai Nasdem dan Partai Gerindra adalah dilakukan dengan 3 (tiga) cara yaitu a) Meningkatkan pendidikan politik, meningkatkan pengetahuan, pemahaman pola fikir, wawasan khususnya yang berkaitan dengan politik hal ini penting sebagai amunisi caleg perempuan untuk menyuarakan kepentingan dan tujuan parpol. b) Meningkatkan marketing politic yaitu dengan cara mendampingi, mengawasi caleg terutama perempuan untuk bergerak aktif melakukan sosialisasi, komunikasi kedaerah dapilnya masing-masing, sebagai ajang untuk mempromosikan visi-misi partai dan mempromosikan kandidat caleg terutama perempuan agar lebih dikenal oleh masyarakat selaku pemilih sehingga masyarakat selaku pemilih tertarik, simpati untuk memilih caleg tersebut pada saat pemilihan legislatif berlangsung. c) Meningkatkan partisipasi politik perempuan, merekrut kader-kader sebanyak mungkin sehingga caleg DPRD perempuan yang di usung partai lebih mendominasi dibandingkan laki-laki atau setidaknya memenuhi kuota 6 laki dan 6 perempuan.

Adapun saran yang penulis ajukan, berdasarkan hasil penelitian dan pembahasan di atas adalah sebagai berikut:

1. Hendaknya partai politik lebih meningkatkan pendidikan politik terhadap calon legislatif khusunya pada kaum perempuan, demikian halnya dengan calon legislatif kaum perempuan dapat mengikuti kegiatan pendidikan politik tersebut secara maksimal, dalam rangka meningkatkan pemahaman, pengetahuan perempuan dalam dunia perpolitikan, pemahaman tentang akivitas yang berkaitan dengan kegiatan pemilihan, lobbying, kegiatan organisasi, mencari koneksi sehingga para perempuan tidak awam lagi dengan dunia politik dapat menjadi bekal calon legislatif perempuan dalam upayanya mencari suara agar kelak dapat memilihnya sebagai wakil rakyat yang akan membawa aspirasinya diparlemen.

2. Hendaknya partai politik melalui calon legislatif khusunya pada kaum perempuan lebih meningkatkan frekuensi penyuluhan, komunikasi kepada masyarakat salah satunya melalui door to door, untuk melakukan komunikasi poltik dengan masyarakat, sebagai upaya mempromosikan diri agar masyarakat tertarik dengan agenda program kegiatan, visi-misi yang ditawarkan jika terpilih sebagai wakil rakyat, sehingga diharapkan masyarakat pada saat pemilihan berlangsung dapat menggunakan hak politiknya untuk memilih kaum perempuan

3. Diharapkan kepada masyarakat, keluarga, partai politik memotivasi calon legislatif khusunya pada kaum perempuan agar aktif terjun didunia perpolitikan serta tidak membelenggu dengan budaya patriaki, kaum perempuan dirangkul sehingga mereka bisa percaya diri dalam mengakses ke ranah politik. Perempuan memiliki peresaan yang halus, sifat yang lembut jadi harus menopang kaum perempuan dan memberikan kesempatan yang sama untuk menduduki posisi strategis di bidang politik, agar kaum perempuan mampu mengimplementasikan karakter dasarnya yang halus itu melalui kepemimpinannya dalam rangka memperjuangkan aspirasi masyarakat di parlemen sebagai upaya meningkatkan kesejahteraan masyarakat.

\section{DAFTAR PUSTAKA}

Anugrah, Astrid. 2016. Keterwakilan Perempuan dalam Politik. Jakarta: Pancuran Alam.

Azis, Asmaeny, 2012. Perempuan di Persimpangan Parlemen studi Dalam Perseptif Politik Hukum. Yogyakarta: Rangkang Education.

Cholisin, 2007, Masalah dan Prospek Pembangunan Politik di Indonesia, Jakarta: PT. Gramedia.

Ihromi, 2015. Kajian Wanita dalam Pembangunan. Jakarta:Grasindo.

Kantaprawira, Rusadi, 2014, Sistem Politik Indonesia, Suatu Model Pengantar, Edisi Revisi, Bandung: Sinar Baru Algensindo..

Kartini, 2011, Pendidikan Politik Sebagai Bagian dari Pendidikan Orang Dewasa, Jakarta: Mandar Maju.

Lovenduski, Joni, 2017. Kendala Kaum Perempuan Menjadi Pelaku Politik. Jakarta: Pustaka Media Inti.

Naning, Ramdlang. 2012. Pendidikan Politik dan Regenerasi, Liberty:Jakarta.

Nihiyah, Jaidi Faraz, 2013. Indonesia dan Komunikasi Politik. Jakarta: Fokus Media.

Rogers dan Storey. 2008. Political Communication And Public Opinion In America, California: Goodyear Publishing Company Inc.

Rohyati, 2009. Pilkada dan Pengembangan Demokrasi Lokal. Bandung: Nusa Media Indah.

Rusli, Karim. 2016. Pemilu Demokratis Kompetitif, Yogyakarta: Tiara Wacana.

Soetjipto, Ani Widyani. 2015. Politik Perempuan Bukan Gerhana. Jakarta: Buku Kompas.

\section{Artikel Jurnal}

Feybe M.P Wuisan, 2016, Keterwakilan Perempuan Dalam Politik di Lembaga Legislatif (Suatu Kajian pada Dprd Kota Tomohon periode 2009-2014), Jurnal, Vol 1-7, Fisip Universitas Prof. Dr. Moestopo (Beragama). 
Mursal Maherul, 2019, Analisis Penyebab Rendahnya Tingkat Keterpilihan Perempuan dalam Upaya Representasi Politik Perempuan pada Pemilu Tahun 2014, Vol. III No. V, Jurnal FISIP Universitas Indonesia.

Nofi Sri Utami, 2016. Politik Hukum Keterwakilan Perempuan di Lembaga Legislatif Era Reformasi, Jurnal, Vol 1-14, Fisip Universitas Negeri Semarang.

Novi Yanthy Adelina 2014. Keterwakilan Perempuan Di Dewan Perwakilan Rakyat Daerah Provinsi Sumatera Utara Periode 2009-2014, Vol 1-12, Fakultas Hukum Universitas Andalas.

Sri Zul Chairiyah, 2019, Perkembangan Keterwakilan Politik Perempuan di DPRD Provinsi Sumatera Barat (Studi Komparatif Kebijakan Affirmative Action Periode Pemilu Legislatif 2004-2014), Vol. 2 No. 2, Jurnal Fisipol Universitas Andalas, Sumatera Barat.

Totok Inwantoro, 2019, Faktor-Faktor Yang Memengaruhi Redahnya Tingkat Partisipasi Politik Perempuan Pada Pemilu Legislatif DPRD Kabupaten Mojokerto 2014, Vol. 2 No. 1, Jurnal Fakultas Ilmu Sosial dan Ilmu Politik Universitas Diponegoro.

Ukhti Raqim, 2016. Implementasi ketentuan kuota 30\% keterwakilan perempuan di DPRD Kota salatiga, Jurnal, Vol 1-9, Fisipol, Universitas Negeri Semarang.

\section{Peraturan Perundangan :}

Undang-Undang Nomor 8 Tahun 2012 Tentang Pemilu

Undang-Undang Republik Indonesia Nomor 7 Tahun 2017 Tentang Pemilihan Umum

Undang-Undang Republik Indonesia Nomor 8 Tahun 2015 Tentang Perubahan Atas Undang-Undang Nomor 1 Tahun 2015 Tentang Penetapan Peraturan Pemerintah Pengganti Undang-Undang Nomor 1 Tahun 2014 Tentang Pemilihan Gubernur, Bupati, Dan Walikota

Peraturan KPU Nomor 7 Tahun 2013 Pasal 11 tentang Tata Cara Pencalonan Anggota DPRD

Keputusan Komisi Pemilihan Umum RI Nomor 271/PL.01.3Kpt/06/KPU/IV/2018 tentang penetapan dan alokasi kursi DPRD provinsi/kabupaten/kota 
Journal of Research in Social Science and Humanities, 1(2), December 2021, - 42 